\title{
ISLAMIC BEAUTY \\ Socio-Semiotic Analysis of Facial Foam and Body Lotion Advertisement ${ }^{1}$
}

\author{
Susi Herti Afriani \\ IAIN Raden Fatah, Palembang - Indonesia
}

\begin{abstract}
This paper attempts to answer how Islamic Women define the concept of beauty in Ponds advertisement white beauty facial foam and body lotion on television. This study uses a socio-semiotic approach described through three aspects of social context, namely field, tenor, and mode. It argues that Ponds' definition of a beauty only refers to physical standards, that is, women who have white skin and use both Ponds White Beauty Facial Foam and Foam Body Lotion. Further, television through Ponds advertising is considered as a commercial institution that supports the main idea of capitalism. However, Islamic women consider beautiful physically and spiritually. It suggests that the beautiful women are those who obey and surrender to Allah SWT. In short, Islamic women do not agree with the meaning of beauty resulted from Ponds White Beauty Facial Foam and Ponds Body Lotion advertisement. Rather, beauty consists of both body and, more importantly, soul.
\end{abstract}

Keywords: Islamic women, beauty, advertisement.

\section{Introduction}

To take care of beauty, women are usually loyal to one cosmetic product. The beauty care includes facial and body treatments such as soap, shampoo, lipstick, mask, and facial moisturizer. The consideration and determination to choose a beauty brand could not

\footnotetext{
${ }^{1}$ The earlier version of this paper was presented at The $12^{\text {th }}$ Annual International Conference on Islamic Studies (AICIS), held by the Ministry of Religious Affairs and the State Institute of Islamic Studies (IAIN) Sunan Ampel, Surabaya, 5-8 November 2012.
} 
be separated from cosmetic advertisement (ads). Usually, cosmetic manufacturers introduced their products through creative ads especially on television. This is because television has a big "power" to inform the products effectively.

The ads visualization is varied and very interesting. Therefore through the attracting ads which is aired in duration from 30 seconds to a minute, the cosmetic company as the sellers can influence the viewers to buy their product. For example, the advertisements of skin care products bombard viewers with the images of white skin. The consumers are given information that skin white is beautiful, so continuously that reality is not really necessary anymore (Reuters, February 2001). It means that manufacturers construct "whiteness" into the viewers mind as a beauty.

Actually, cosmetic advertisement has been regulated in Decree No. Permenkes.386/1994. It prohibits the ads depiction that may affect the physiological and or metabolism of human body. It also prohibits the use of words "treat, cure or other words that convey the same as if to treat a disease". The problem in the skin whitening advertising, although the language is not against the rules, is the perceptions generated that stating as if the product has a therapeutic effect namely therapy "to be white". ${ }^{2}$

In Indonesia, whitening facial advertisement created by Ponds Institute Company got huge attention from the TV viewers. It can be seen when Ponds white beauty ads won Brand Award given by Citra Pariwara for 3 consecutive years by. The advertisement assessed from the images, sounds, situations, and language used. In this case, Ponds advertisement was able to see the target smartly. Ponds has succeed perceiving "beautiful" as having white skin and Ponds is capable of bleaching the face.

In general, advertising is a promotional media for marketing the products and services through mass media. ${ }^{3}$ The increasing number of the advertisements is in line with the emerging of private televisions in the era of 1990s. Private TV then became "fine cuisine" for advertisers. Here, advertising affects people in two ways. Firstly, ads is an instrument of marketing communication. It advertised the works to

\footnotetext{
2 Kompas," YLKI: Krim Pemutih Mengandung Merkuri," (14 May 2001).

${ }^{3}$ B. I. Purwantari, "Mencipta Makna tentang Perempuan lewat Iklan," Jurnal Perempuan, 06 (February-April 1998), p. 39
} 
sell the products, services and ideas through persuasion. Second, it is as a form of social communication. It offers a message to the community and helps them to shape and understand the social world. ${ }^{4}$

Furthermore, advertising is not only has an economic power, but also has a cultural significance. It is clearly that television is the most effective medium for advertisers in conveying their advertising messages communicatively. However, does Ponds advertisement aim to help consumers in selecting products or just made solely in the interest of producers which deals with the meaning of advertising Ponds. Based on the explanation above, This study intends to examine the problems (1) Is it true that Ponds advertisement is a form of communication which full of meaning?; (2) What is the form and function of the meanings which is realized in society?; and (3) How Islamic Women defines "beautiful" in Ponds White Beauty Facial Foam advertisement and Ponds Body Lotion on television?.

\section{Theoritical Framework}

An early model of communication and discourse analysis is derived from the perspective of the communication process developed by Shannon and Weaver.

Figure 1: Shannon and Weaver's General Communication Model $^{5}$

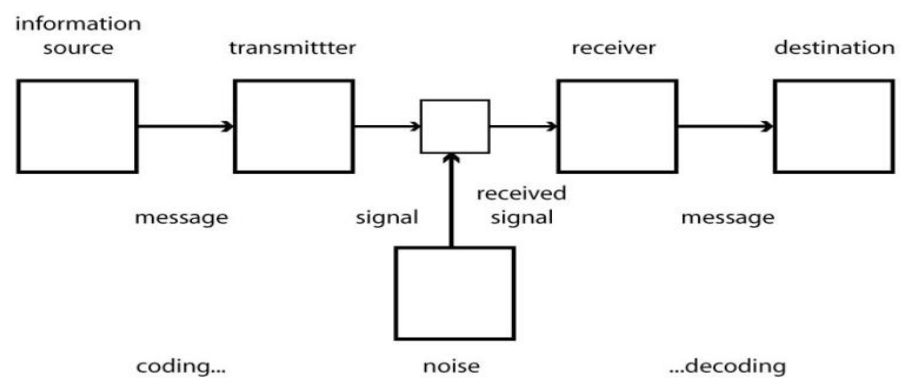

Above figure is well known as one of the basic models in communication science, which describes the communication process as a simple and linear process. Renkema ${ }^{6}$ describes the communication

\footnotetext{
${ }^{4}$ Dean M. Krugman Reid and Leonard N, Advertising: It's Role in Modern Marketing (Orlando: The Dryden Press, Harcourt Brace College Publishers, 1994), pp. 37-38.

${ }^{5}$ J. Renkema, Discourse Studies. An Introductory Textbook (Amsterdam/Philadelphia: John Benjamins, 2004), p. 40.

6 Ibid., pp. $40-41$
} 
model in figure 1 as follows: information source (source of information) is considered as the decision maker, that is, it chooses or selects message to send. The selected message consists of written or spoken language, images, music and so on. The transmitter encodes the message in a signal that is sent through a communication channel to receiver. The receiver translates the signals into message, then encodes the message and sends this message to destination. The important thing in communication theory is that the message encoded into words, and then distributed through a channel of communication, voice, paper, and screen to the receiver. The next step is the receiver encodes the message from the signal, and then he sends it to the destination, namely readers or audiences.

Another theory used to analyse the data in this research is discourse analysis. It is a method aimed to investigate the relationship between form and function. ${ }^{7}$ Discourse refers to the complexity of aspects formed by the interaction among the linguistic aspects of the text, which embodied in the outer aspect of language. 8 In addition, Aminuddin states that the interaction not only determines the characteristics of the form of communication or the use of language, but it also determines the meaning of a text, which is influenced by elements outside the language of the participants, purpose and context. In linguistics, the context includes the context of the speech, the context substitutions such situations, the medium used, the location, the persona and the conditions that allow for substitutions. Besides that are cultural context and reference to the context of the conversation context. ${ }^{9}$

Meanwhile, Cook $^{10}$ explains that discourse analysis is related to the context of the communication: who and with whom speakers communicate and why; what kind of people and how the situations, through what medium, how the difference of types and actions including communication and interaction each other. Regarding the discourse of advertising, Cook explains that it is a combination of text

\footnotetext{
${ }^{7}$ Ibid., p. 1

8 Aminuddin, Analisis Wacana dari Linguistik sampai Dekonstruksi (Yogyakarta: Kanal, 2002), p. 37.

${ }_{9}$ Ibid., p. 38

${ }^{10}$ Guy Cook, The Discourse of Advertising (London: Routledge, 2001), p. 3.
} 
(linguistic form) and context (substance; music and pictures; paralanguage; situation; co-text; intertext; participants; function). ${ }^{11}$

\section{Production of Meaning in Advertising}

Stuart Hall in his book "The rediscovery of Ideology" said that the meaning or image appearing in an advertisement is the result of a particular way of constructing reality. Furthermore, he argued that reality is produced through practices of linguistic and visual, in which the practices are definitions of reality are selectively represented. Regarding to reality which is constructed by advertising, Rymond William in Bungin said that television advertising has become the magic system. ${ }^{12}$ Whilst Piliang argued that the social reality in television advertising has reinforced your power as something real going on called hiperreality. ${ }^{13}$

Bungin stated that in addition to categorization of meaning encoded by viewers in different social classes, the meaning of which has been encoded by viewers, is also associated with the image created by the copywriter in the advertisement. ${ }^{14}$ Furthermore, the encoding process by viewers using an arbitrary interpretation of the meaning encoded so that will vary. In addition, emphasis will be the interpretation of the advertising done by Purwantari with his opinion that the events in the real world do not contain their own meaning an integral and intrinsic which is then transferred through language. Rather, the meaning is a production and social practice in which the language and symbolism is a tool that allows meanings to be produced.

\section{Discourse Aspects of Meaning}

This study uses Halliday and Hasan theory (1985) to examine the data as quoted by Renkema ${ }^{15}$ through a socio-semiotic approach. Renkema describes three aspects of the social context, namely: (1) field, (2) tenor, and (3) mode. These concepts allow interpreting the social context of discourse, in which the meaning is sometimes altered. A field is a field of discourse that refers to what happened and the nature of social action that occurred. Analyzing this aspect more

\footnotetext{
11 Ibid., p. 4.

12 Burhan Bungin, Imaji Media Massa (Yogyakarta: Jendela, 2000).

13 Yasraf Amir Piliang, Hiperrealitas Kebudayaan (Yogyakarta: LKiS, 1999).

14 See Bungin, Imaji Media Massa.

15 Renkema, Discourse Studies, p. 46.
} 
focuses on the features of language used by participants. In general, the contents of the field are what discourse is. ${ }^{16}$ This aspect is also called as an ideational meaning (the meaning of the idea) and an ideational function, namely the function of language to express "something" as represented by speakers. ${ }^{17}$ Aminuddin added that the linguistic meaning of the symbol is not only shaped by the linguistic aspects, but also by the views of language user in perceiving the world and abstract linguistic symbol which is referenced.

Whilst, tenor is a discourse that refers to who is taking part in the discourse, the nature of the participants which refers to their status and roles in the discourse. ${ }^{18}$ Tenor describes the relationship among the models of ads. The analysis process focuses on power and social status, which can be seen through the vertical relationship (low/high social status), and horizontal relationships (far/close solidarity).

Mode refers to the part where the language plays an active role and the function of language is being used to do. In addition, mode is the symbolic organization of the text, status, and its function in the context, including the channel (oral, written, or a combination of both channels) as well as rhetorical mode ${ }^{19}$. So mode is talking about the superstructure mode, purpose and function. Further, these three aspects of social context are related to three aspects of discourse, namely ideational, interpersonal, and textual. Renkema said that the meaning is associated with the discourse to the context. In relations to discourse and context for semantic level of semiotics, it is clearly explained in the chart below:

Figure 2: Key Concepts in Functional Grammar

\begin{tabular}{ll}
\hline Situational Component & Discourse Aspect \\
\hline Field & Ideational meaning \\
Tenor & Interpersonal meaning \\
Mode & Textual meaning \\
\hline
\end{tabular}

From the figure (2), it appears that the meaning of the idea of a discourse is associated with the field components of a situational

\footnotetext{
16 Ibid.

17 Aminuddin. Analisis Wacana, p. 41

18 Renkema,. Discourse Studies, p. 46

19 Ibid., p. 47
} 
context. It means the content of discourse refers to what happens in a particular situation or a particular topic. Ideational meaning should be able to answer questions about discourse. ${ }^{20}$ Meanwhile, Renkema says that the meaning of interpersonal discourse related to tenor, and can be recognized by the participants in the discourse of how to use language to act. For example, the use of the type of job means someone who has the "power" to give instruction. The last aspect of discourse in the table (1) is a textual meaning associated with fashion. Textual meaning is defined as the organization of the content elements within a larger structure. In this study, there are two versions of Ponds advertisement will be analyzed. First is Tennis Version, and the second is Walking on the Crowd Version.

\section{Ponds Advertisement: Tennis Version}

The Tennis Version is the latest ads of Ponds advertisement aired in 2006 featuring two women were playing tennis in the international tennis competition. It showed the Wimbledon stadium; the headquarters of the All England Lawn Tennis and Croquet Club in London suburb. The first woman is black skinned as the main player. Another woman is white skinned as co-star. Ponds Tennis Version on television advertisement can be read as follows:
Mainnya makin bagus..., wajabnya tampak makin putih... (Narator
iklan) karena ia memakai Ponds Moisturizer dan juga Ponds Facial
Foam, yang mengandung Vitamin B3 untuk membantu Ponds
Mousturizer lebih meresap ke dalam kulit agar tampak. lebih putih.
Langkab awal untuk kulit wajah tampak lebih putib... Ponds White
(she is playing better ..., her face looked whiter ..., (ads narrator) because she is wearing Ponds Moisturizer and Facial Foam, which contain Vitamin B3 to help Ponds Mousturizer more absorbed into the skin to look whiter. The first step to whiten skin ... Ponds White Beauty Facial Foam).

\section{Ideational Meaning}

In examining ideational meaning, requires considering the component of situation in the ads. As stated in the previous explanation, field and component of situation in the sense that this is a field of discourse refers to what happened and the nature of social action occurred, particularly participants answered questions about what is included in it, can be seen from the features of the language.

20 Ibid. 
Figure 3: Ponds tennis version on television advertisement

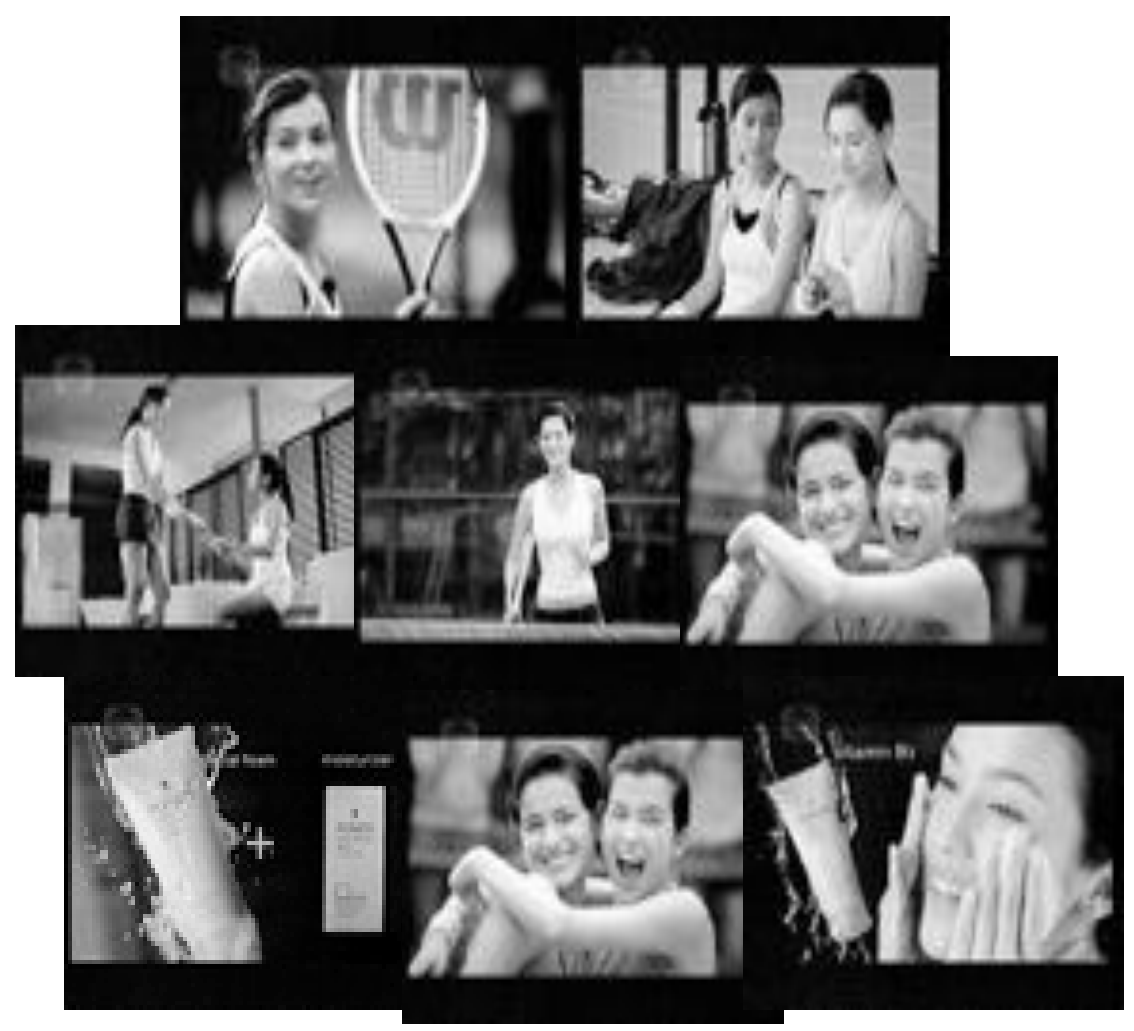

"Her playing better ..., her face looked whiter ..." This sentence denotes that there are two models who have different skin color, they are, brown-skinned and white-skinned women. In this context, ads maker is the seller who has particular interest to sell the product, and the the television audiences are as targeted consumers of Ponds products. In fact, the targeted consumers are white women, because actually (the sentence... her face looks whiter ...,) aimed to women who already have a white pigment. Furthermore, the ideational meaning should be able to answer questions about discourse. In the context of tennis version, the ads describes the product called Ponds Moisturizer and Facial Foam, which contains vitamin B3. So, there are two products to sell. The first kind of moisturizer is to using after shower), the second one is a cleanser or soap. This ads supposed to sell both 
products simultaneously by saying that women should use soap before applying moisturizer, because the function of Ponds Facial Foam, which contains vitamin B3 is optimizing Ponds Moisturizer to seep into the skin to be whiter. Therefore, the first step to whiten the skin is actually Ponds White Beauty Facial Foam.

\section{Interpersonal Meaning}

Let consider the example (1) below. (1) ..., (ad narrator) because she was wearing Ponds Moisturizer and Facial Foam, which contain Vitamin B3 to make Ponds Moisturizer more absorbed into the skin to appear more white. The first step to white skin... Ponds White Beauty Facial Foam. The interpersonal meaning can be determined by looking at the Tenor as a discourse that refers to who is taking part in the discourse, looking into their nature that is referring to the status and role in the discourse. ${ }^{21}$ Tenor describes the relationship among the models of ads. The analysis process focuses on power and social status, which can be seen through the vertical relationship (low/high social status), and horizontal relationships (far/close solidarity).

For example the use of narrator in ads is very effective because the narrator's speech has a "power" in communicating the message. Through narrator, television gives the image which is processed into raw materials marketing. It gives the viewers information, especially the targeted consumers, that using the Ponds will have skin white, and the whiteness is "beautiful". "Ponds Moisturizer and Facial Foam, which contain Vitamin B3, will be absorbed easier and faster into the skin to make it whiter". Television via Ponds advertisement has a major role to make the products as commodities. Ponds have to rely on advertisement to get big fund revenue (possibility). Further, to conceptualize the production and reproduction Ponds ads serves the commercial institutions that support the main idea of capitalism (selling all kinds of Ponds products). In this context, Ponds does not provide information to consumers in to make their best choice, it only promotes its own products with the memorable slogan "the initial skin look whiter", namely Ponds White Beauty Facial Foam.

Mode refers to the part where the language plays an active role and the function of language is being used to do. Mode is the arrangement of text, status, and its function in the context, including the channel (oral, written, or a combination of both channels) as well as rhetorical

21 Ibid. 
mode. ${ }^{22}$ In short, it is talking about the mode shapes (superstructures), it is purpose and function.

Ponds advertising language on tennis version represents advertising producer's interest as the sellers. Manufacturers suggest that every woman who buys and uses Ponds will make her skin whiter, whiter and whiter. The word "whiter" is repeated several times intended to construct the perception of the viewer (the target) that this faces whitening products are really "effective" to whiten the skin. The Ponds advertisements on television changes the people lives significantly. First, this advertisement user cultivates the desire for being "white", because white means "beautiful". It means that many women are motivated to imitate what they see on television, such as using Ponds Facial Foam followed by Ponds Moisturizer. Moreover, television uses one way communication, that the women will be forced to seek external information to have healthy skin that they do not find in Pond's.

\section{Advertisement of Ponds "Walking on the Crowd" Version}

In this version, the advertisement illustrates two women are walking on the crowd. They were walking on the opposite direction. One of them has a white skin (called white skin model) while another one has a black skin (called black skin model). The black skin model looks at the white skin model from the distant and suddenly focuses her sight on the white woman's skin. In this advertisement, actually the two women is not the main issue. The point is the white skin model's action who gives ponds product to the black one when they meet. In this ads the narrator says:

Ngapain takut belang, sekarang ada Ponds Body Lotion Baru yang melengkapi putibmu sampai ke ujung kaki.

(Why do you fear of stripes? Now days, New Ponds Body Lotion will complete your whiteness until your toes)

\section{Ideational meaning}

Similar with the previous ponds advertisement, walking on the crowd version also uses two figures who have different skin color, namely black (brown) and white skin. The depiction of this discourse can be seen through the narrator's speech (2) which means if the black skin model wants to have white skin so she has to use New Ponds Body Lotion as given by the white skin model. As the previous explanation,

22 Ibid. 
the meaning of the idea should be able to answer the discourse purposed. First, the advertisement is actually just presenting the latest product of the Ponds. It wants to deliver a message that the product is for women who are skinned striped or white skin evenly to toe.

Figure 4: "walking in the crowd version" television advertisement of Ponds

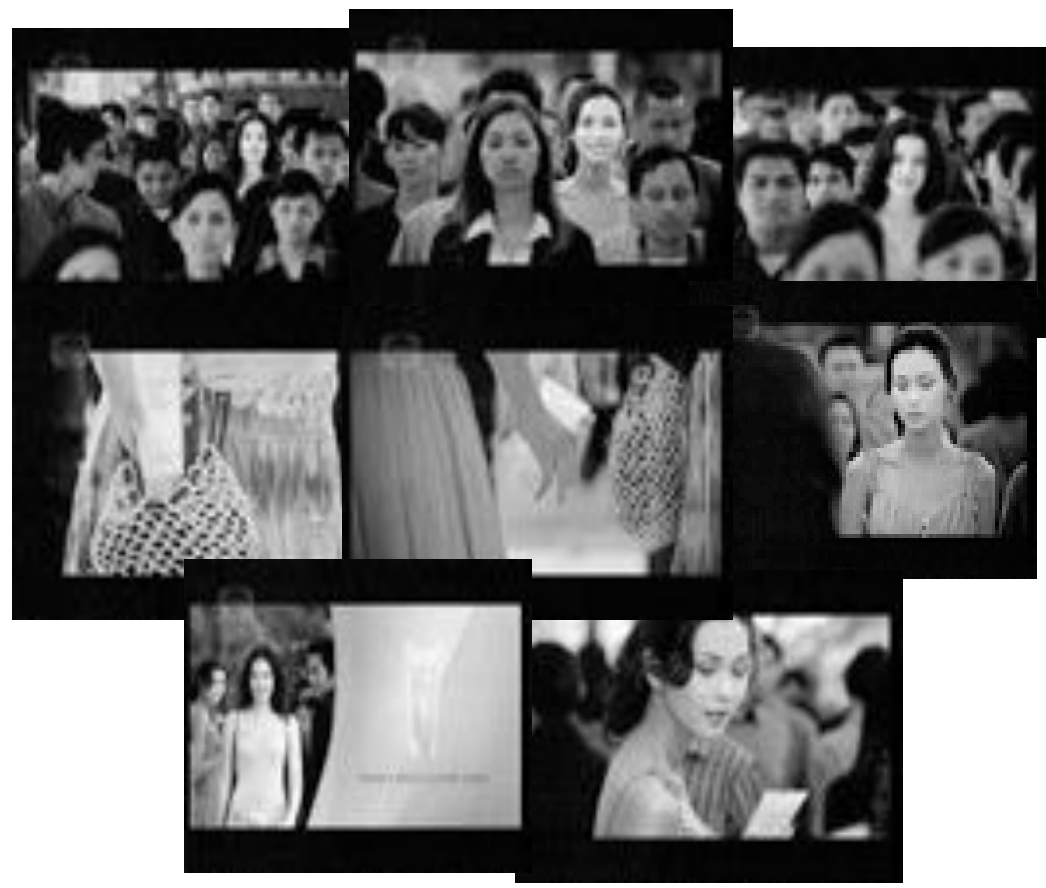

This new product is trying to lure viewers to use Ponds Body Lotion, so "whiteness" will spread from face to toe. If the whiteness spreads to all the women body from face to toe so the women are being "beautiful". Second, the advertisement talks about the comparison between white and stripes skin. The manufacturer indicates that white women get more "attention" from the men (the ads shows that most of men around them just look at the white skin woman but not at black skin woman). Therefore, it can be stated that the benefits of the product in treating female beauty is really highlighted by advertisers with the assumption that women should take care of their beauty in order to attract the opposite sex. 


\section{Interpersonal meaning}

Renkema ${ }^{23}$ says that the meaning of interpersonal discourse related to the tenor, the status and role of the participants, and can be recognized by the participants in the discourse about how to use language to act. For example, the use of the type of job refers to a person who has "the strength (power)" to give instruction. Language used on the advertisement "walking on the crowd "is informative as well as persuasive "Why fear stripes, now days the New Ponds Body Lotion will complete your whiteness until you toes feet". The advertising manufactures provide information on television that Ponds launch a new product using creative words "why fearing stripes" which mean "beautiful" is having evenness white skin.

\section{Textual Meaning}

The last aspect of discourse is related to the meaning of textual mode (mode). Textual meaning means the organization of the content elements within a larger structure, for example, where the perspective on a topic related to the technique of putting the information in a prominent place. Here, Ponds advertisement put new information about a new product that can whiten the skin to toe. This means, it appears that manufacturers impose Ponds consumption as many as possible to television viewers as the main purpose namely product propaganda. Ponds advertisement manufacturers encourage the consumers to buy as many products as possible because of the thought that the more the consumers buy the product the greater the benefits. This consumerism propagated by advertising Ponds up to the level of imaging that using "Ponds" is equivalent to the beauty itself. When women do not buy the product that woman does not have the beauty "product version Ponds".

The commercial efforts to encourage the consumers to buy Ponds products are dishonest and deceptive. This is because the commercial models used in the ads are already white skinned and "beautiful" based on the standard of beauty in Indonesia (tall and slender, long black hair, white face, "beautiful"), also it is illogical that the product with the price ranging from $\mathrm{Rp} 10.000$, - up to Rp 12.000, - can whiten the skins in as few as 6 weeks. Therefore it can be said that Ponds advertisement spreading the idea to the public that he black or brown skin women need to buy products Ponds in order to become beautiful

23 Ibid. 
is a public lie. Unfortunately, for making mutual relations, the propaganda carried out by the manufacturer Ponds advertisement is fully supported by television; it can be proven by the presence of advertising airtime Ponds every advertisement.

\section{Conclusion}

Ponds advertisement is a kind of communication form which is full of meanings. The form and function of meaning in advertising Ponds White Beauty Facial Foam and Ponds Body Lotion on television is portrayed through ideas, ads language, and purpose. "Beautiful" in this ads are women who have white skin and use all kinds of Ponds products. They are good moisturizer, cleanser, moisturizer and a flattened body to toe white. The manufacturers construct an image to form a consumer (especially women) mind in the physical standards. To conceptualize the production and reproduction, television via Ponds advertising treated itself as a commodity and served as a commercial institution that supports the main idea of capitalism.

Based on the explanation above, the meaning and definition of "beautiful" according to Ponds White Beauty Facial Foam advertisement and Foam Body Lotion advertisement only refers to physical standards, in that a beautiful woman refers to a woman who has white skin further evenness white skin. It is done from all aspect of Ponds advertisement-Ideational meaning, interpersonal meaning, and textual meaning - where all the meaning of those advertisements take "benefit" from tendency features, which is attributed to every women, especially Indonesian women who always try to be beautiful. Women representation that appears on the Ponds advertisement does not show the representation of Islamic woman where the inner beauty is beauty from body and soul.

Islamic women consider beautiful physically and spiritually. Islam suggests the beautiful women are those who obey and surrender to Allah SWT. It is also clear that the Islamic women does not 'live' in the standard of beauty from images that bombarded by advertisement of Ponds White Beauty Facial Foam and Ponds Body Lotion. In short, Islamic women are not supposed to agree with the meaning of beauty resulted from Ponds White Beauty Facial Foam advertisement, and absolutely they also disagree with the meaning resulted from Ponds Body Lotion advertisement. The women represented in these advertisements are only for capitalism products. [] 


\section{Bibliography}

Books and Articles

Aminuddin. Analisis Wacana dari Linguistik sampai Dekonstruksi. Yogyakarta: Kanal, 2002.

Burhan, Bungin. Imaji Media Massa. Yogyakarta: Jendela, 2000.

Cook, Guy. The Discourse of Advertising. London: Routledge, 2001.

Krugman, Dean M. Reid and Leonard N. Advertising: It's Role in Modern Marketing. Orlando: The Dryden Press, Harcourt Brace College Publishers, 1994.

Kompas. Putih itu Cantik, tidak Putih juga Cantik. 25 February 2001.

Kompas. YLKI: Krim Pemutih Mengandung Merkuri. 14 May 2001.

Piliang, Yasraf Amir. Hiperrealitas kebudayaan. Yogyakarta. LKiS, 1999.

Purwantari, B. I. "Mencipta Makna tentang Perempuan lewat Iklan." Jurnal Perempuan, 06 (February-April 1998).

Renkema, J. Discourse Studies, an Introductory Textbook. AmsterdamPhiladelphia: John Benjamins, 2004. 